\title{
Intervention and Sovereignty in Environmental Protection: The Disputation of the Developing Countries' Role
}

\author{
Luxi Jiang ${ }^{1, *}, \dagger$, Shuying Zhang ${ }^{2, \dagger}$ \\ ${ }^{1}$ School of philosophy, Beijing Normal University, Beijing, China \\ ${ }^{2}$ Foreign Languages, Nanjing University of Posts and Telecommunications, Nanjing, Jiangsu Province, China \\ ${ }^{*}$ Corresponding author. Email: 201911031217@mail.bnu.edu.cn \\ These authors contributed equally.
}

\begin{abstract}
The international intervention has been criticized by the developing countries as a political weapon to interfere with their sovereignty by developed countries. This article compares the changing strategies from Trump to the Biden government with the theoretical explanation. Through such comparison, it is argued that the failure and developing countries' fight back against the so-called humanitarian intervention have both the deficiencies in practical reason and theoretical traditions.
\end{abstract}

Keywords: United States government, international intervention, humanitarian, sovereignty

\section{INTRODUCTION}

International intervention is an act of interference in the relations between other countries or in their internal affairs from the outside, led by an international organization or a state, and can take many forms, including military, economic, political, and war, such as making critical statements, imposing economic sanctions, sending troops to take military action, and other acts of intervention of varying degrees. The concept of international intervention is derived from the post-Cold War concept of national sovereignty, and most of the governments of countries or regions that intervene internationally do so from a "humanitarian" point of view [1-3]. In today's world, globalization is an inevitable trend of development. This means that the interconnection and influence between different countries and regions will deepen, which also lays the temptation for them to try to interfere with other countries. In the current international environment, international intervention is more often seen in a series of initiatives led by developed countries against developing countries, which is also related to their historical origin and espoused moral ideology. The frequent international interventions in recent years reflect the imbalance of power between different countries, which is objective and difficult to change in a short time [4]. Some supporters of international intervention see it as an effective way to reconcile contradictions, resolve conflicts, and even express justice. Others who disagree believe that no matter how valuable and convincing a shell is given to international intervention, it cannot conceal the fact that it is an act that violates the sovereignty of other countries and has coercive intervention as its core.

As one of the most powerful countries in the world, the two administrations of the United States' distinct international intervention policies are very informative, which is why it was chosen as the specific case for analysis in this article $[5,6]$. Through the analysis of this case, several key factors that influence international interventions, as well as some patterns can be observed. The interaction between countries is very frequent in recent years, and the competition between major powers is even more pronounced. It is well known that interests are the determining factor of countries' foreign policies. The rapid development of other countries is perceived by some powers as a threat to them, which forces them to take some actions to secure their position. Even though the principle of non-interference is included in the accepted basic norms of international law, few powers can comply with this norm of behavior in international relations. 
There is no doubt that the causes of international interventions are very complex, and through case studies and historical tracing, some of the main factors can be summarized as much as possible. For example, the detailed analysis in the article about the influence of US political partisanship on international intervention policies. Different parties have different attitudes toward intervention in other countries affairs. In addition, the influence of cultural and historical background on international intervention is highlighted in this paper, which is well documented. From the historical and cultural point of view of the United States, the politics of intervention has been advocated since a long time ago, and the political ethics they learned taught them to be "responsible", especially for maintaining the order of the world they live in, while from the point of view of other developing countries, "sovereignty" is the most important [7]. "borders", which cannot be easily touched. This is also the result of the war and aggression they have suffered for centuries and the unstable living environment they have. Finally, through the case study of the U.S. government and the study of historical background, the future direction of international intervention is also a topic worthy of deeper consideration. Will such actions with coercive connotations always work? Will other countries take countermeasures to alleviate the pressure exerted on them by international interventions? The world is now a pluralistic place, where international discourse is no longer confined to a few major powers, as in the case of China's value of "community of human destiny," where more and more countries are willing to make their voices heard and fight for their rights, rather than passively accept and be exported.

\section{THE TRUMP GOVERNMENT}

From the recent trends in international relations, it is easy to discover the dramatic changes in the international situation and its profound influences. The relationship between the US and China, two of the largest economy, plays an important role in the changing trends. The relation between US and China has witnessed tremendous transformation in recent years, especially when Trump came into power. Beneath all kinds of conflicts in the economy, politics and diplomacy lies the true competition of comprehensive national strength and ideology, which reflected as the conflict between intervention and refused to be intervened, and showed remarkably in the process of US withdrawal from the Paris Agreement. One of the most important decisions Trump made in his tenure was to withdraw from the Paris Agreement, a legally binding international treaty to limit climate change. The decision to exit was announced in 2016 , while it officially came into power in 2020 . Since the agreement was adopted by nearly 200 parties and the US has played an active role previously, the withdrawal nowadays has caused much of a stir for it not only affected the US domestically but also brought great changes to the international world, especially for China and Europe who were the two largest components of the agreement. China has already had a heated discussion about the withdrawal, which mainly focuses on the devasting influences on future climate issues and the role China would play in the coming years. Three Chinese scholars, Shao Sujun, Rong Xue, and Zheng Fangyuan, use the model of game theory to analyze the uncertainty of the post-Paris Agreement policy which aimed to find solutions for constraints and incentive mechanisms. Scholars in the National Climate Center in China have illustrated the foreseeing consequence of the US's withdrawal. According to their study, the low-carbon pathway and transformation trend of the global climate regime will not be changed from a global perspective, while the long-term goal and the disputation of responsibilities of climate change will be impacted due to the budget cut on domestic climate change research and the donation cancelation on the multilateral environmental fund from the United States. With America initiatively abandoning the leading role in climate issue globally, it is a good opportunity for China, along with other third world countries, and the sub-state actors such as the NGO, cities, and companies to take the lead. It is analyzed that due to China and India's active participation in dealing with climate changes, the $\mathrm{CO} 2$ emission is predicted to be cut by 200-300 million tons, which largely outweighs the negative impact brought by US's withdrawal. Meanwhile, it is stated by scholars in China that Trump's decision of withdrawal is an action to avoid shouldering the responsibility on climate change. They argue that the environmental problems nowadays are mainly caused by the developed countries in their industrialization process, thus they should shoulder more responsibilities on dealing with the problems, which by the rules raised by the Paris Agreement, the "common but differentiated responsibility principle". What Trump is trying to do is get America out of its international liability, and leave the role of global governance to other countries. This movement that goes against the basic principles recognized internationally on the one hand hurt the reputation of the US seriously, and give other countries, such as Europe and China, the ambition to take the lead internationally, while it on the other hand harm the longterm economic growth for the US, since the price of renewable resource continued to drop and has become closer and closer to the price of fossil energy such as coal, which made Trump's commitment on revitalizing the mining industry unlikely to come true. While most of the countries nowadays are seeking science and technology growth, the US is taking the opposite road, trying to give up its advantages in innovation and return to a traditional industry. This, argued by many scholars, could be seen as a turning point of the balance of power between the US and China [8]. With the US struggling in social fragmentation, China got the chance to boom as unitedly. In many Chinese points of view, the four years of Trump's 
tenure provide an excellent chance for China to develop independently. Although there are worries about the future trend of climate change, most Chinese scholars remain positive of the future environmental cooperation, because they believed that the unilateral withdrawal is unable to terminate the Paris Agreement, as the framework set the agreement is positive, firm, open, and progressive by nature. However, they also believed that the US withdrawal does not necessarily mean that the US is to give up its leadership in the climate process or that China is about the take over the role left by the US. Chinese scholars raised a concept of "actively lead, but limited liability", which emphasis China to become more active on the international stage, while not replacing the role of the US at the same time. This is because China still lacks the governance and finical abilities to shoulder unlimited responsibility, and China does not want to intervene in other countries for environmental reasons. It is well-recognized in the Chinese context that future climate issues can be solved as long as all the other countries stay united, and since the US is gradually losing its credit and power internationally, China can seize this period to enlarge its right of speech globally when the US is working hard to retrieve their global governance. However, China is unwilling to play the role left by the US, it, on the one hand, showed that China, as a nonWestern developing country that differs from the European countries, values sovereignty more than universal values such as environmental protection, so that it does not want to get too involved into other countries internal affairs. On the other hand, it is undeniable that China is still not ready for becoming one of the biggest international forces. As Amitav Acharya writes in his book, "the end of the American world order", that although the American World Order is weakening nowadays, future world orders are likely to maintain the one led by the US. He estimated that non-Western countries still lack the abilities to manage important international issues despite their hard work to enlarge their right of speech [9]. As the world's second-largest economy, China remains its policy of noninterference that is rather passive. With its enlargement of international power, more international responsibilities are inevitable to come along. This is what US and China have been arguing about heatedly. In most of the Western countries' perspectives, including the US, that China's total GDP already reached the standard of becoming a developed country, thus China must shoulder more international liabilities on non-profit movements such as environmental protection or humanitarian intervention. While China, on the opposite, still claimed to be a developing country for its large population had made its per capita GDP fail to reach the developed countries standard. With China continuing to develop, the dispute on the division of power and responsibility will continue to grow, and China has to face it unavoidably. Whether like it or not, the US has truly made great efforts into common concerns like climate change in the past several years. Today's China is facing a turning point on the international stage with the contradiction of power and responsibility. If it remains its passive attitude towards international problems such as climate change, it is likely to miss the vital opportunity to bring China to the next level.

Besides China, the US also has its problem. Trump's undo climate policies were brought on as early as his campaign process. In 2012, he claimed that the climate problem is a concept created by and for the Chinese to make US manufacturing non-competitive and accelerate the Chinese process to replace the US to become a world economic leader. In December 2013, Trump declared global warming a "hoax" because an unusual ice storm stripped through the southern part of the United States, as he wrote, "We should be focused on magnificently clean and healthy air and not distracted by the expensive hoax that is global warming". Statement as "conspiracy of China" or "expansive hoax" was mentioned repeatedly, this shows that as a traditional businessman, Trump has strong prejudice and suspicion towards climate change. The positions of some important departments nominated by Trump, such as Rex Tillerson, the secretary of the US; Rick Perry, secretary of energy; Scott Pruitt, administrator of the environmental protection agency; and Steve Bannon, white house chief strategies in the administration of U.S. President Donald Trump are all skeptic of climate change or have fossil industry working backgrounds. It is believed that Trump has a clear purpose in dominating them, hoping that they can stay on the same front with his undo climate policies. The White House announcement on the draft budget for the fiscal year showed their will to cut the finical support on climate change and the scientific research related, including the APPA-E that has been executed for years. Within less than 100 days after Trump came into power, the Obama climate legacy was deleted from the federal government. All of these measures release the signal that Trump is trying to alter the traditional strategy towards China which combines humanitarian intervention, using public opinions and moral high ground, and competition into a new mode with tough altitude and straight confrontation. Besides factors of Trump's personality that leads to today's situation, the realism factor is also playing an important role in the transformation of the US's policies towards China. Previously, the US has always used the environmental issue as means to intervene by accusing and isolating China with pressure from public opinions. This is because the US was much more powerful than China in the international world, which enabled it to have advantages when accusing China of humanitarian issues, and China used to be unable to refute. Trump, unlike other traditional politicians in the US, gave up all the moral high grounds that the US used to have, and used unprecedented harsh speech against China with the severely tough position through his campaign process to his four years' tenure. 
The tension between US and China has become a fierce conflict, which is partly due to the change of power between the two countries. While China's economy continued to grow at the surprising rate of about $7 \%$, the American economy was rather stable. The rapid development of China has drawn the world's attention. Whether out of Thucydides' Trap or simply out of the huge gap in ideology, many US politicians were alerted to see China's development, among them Trump was an extreme one. Due to the change of power between the US and China, the Trump administration found that it is unlikely to constrain China with traditional strategies using international public opinions and ideologies, so they chose an urgent and radical way. The US-China relations nowadays with more direct conflicts does not mean less intervention. It is the upgrade of intervention under the condition of similar power. Both direct conflict and indirect intervention point to the international governance of the US, and function as means to balance the world power benefited to the US. In other words, direct conflicts between US and China are inevitable, and Trump only accelerates the process. It is not simply about climate change, but a contradiction of the traditional Western intervention and world order with the ongoing booming of the non-Western country. The upgrade of the intervention is based on China's gradual loss of the environment for indirect humanitarian intervention since China is enlarging its power globally while strengthening the centralization of power domestically, making it hard to weaken by public opinions. Back in 1999 when the Chinese embassy in Yugoslavia was bombed by NATO, the Chinese government chose to solve this with a mild and compromising diplomatic attitude although it was a disastrous event and seriously outraged the Chinese people. On the contrary, when seeing the BCI, better cotton initiative, accused China of forced labor in XUAR in 2020, the Chinese government acted swiftly to counter by using tough diplomatic language internationally, while inciting the patriotic enthusiasm and calling for boycotting related brands domestically. The transform of the attitude China chose to have when facing opponents is partly attributed to the growth of its national strength, which gives them the confidence to react directly towards objections and be more aggressive. This can also be attributed to the political operation China used in the past years. By strengthening ideological unity---which can be seen from the expression raised in the 19th CPC National Congress that emphasis CPC's leadership over all work, from study to politics, from the army to the people---and reinforce its political propaganda, the Chinese government success to govern for all in unity, making the expressions the Western used noneffective to intervene.

Ironically, when Trump was blaming China for using climate change as means to restrain the US, much Chinese public that is led or influenced by a social leader from social media believe that climate change is a concept raised by the West and used for criticizing China.
Conspiracy theories like this became more and more popular in China. Not only climate change, every quarrel on the internet, and every criticism to the government can be seen as the public opinion warfare set by the US; and every problem the government face can be seen as a "big game played by the government to compete with the US". It is easy to notice that conspiracy theories are spreading both in the US and in China. Though points to the opposite side, both the conspiracy theories stand for the same trend in both of the countries---that populism is rising and more and more people tend to see everything as weapons for political struggle but become ignorant of the facts. As one of the effects of the conflicts between the US and China, the world is becoming more extreme, making everything about politics. Consequently, the ultra-left and ultra-right trends are rising, exacerbating world fragmentation.

\section{THE BIDEN GOVERNMENT}

The Biden administration's attitude to environmental protection is very different from the Trump administration's "light on the environment, loose on the regulations", which has worked to pursue more aggressive environmental policies to address growing environmental concerns. On his first day in office, Biden issued seventeen executive orders to change previous Trump policies, with a return to the Paris Agreement and the World Health Organization (WHO) being the two most closely related to environmental issues.

Bringing the United States back into the Paris Agreement was Biden's first major action to address global warming. In his inaugural address, he made clear that solving the "climate crisis" is a priority, noting that "the call for survival comes from the Earth itself." Biden also appointed John Kerry, who served as secretary of state in the Obama administration, as the president's special envoy on climate issues. Kerry played an important role in reaching the Paris Agreement during his tenure as Secretary of State. In addition, on his inauguration day, Biden called a halt to the U.S. withdrawal from the WHO and said he would join the New Crown Vaccine Global Access (COVAX) mechanism. The mechanism works to promote equitable access and distribution of vaccines, especially in poorer countries. Biden canceled the permit for the Keystone XL pipeline from Canada to the U.S., for which Canada expressed great disappointment. In addition, in the U.S. trade policy agenda for 2021, the Biden administration has proposed important policies related to sustainable climate development. Environmental standards, multilateral trade cooperation, and exploration and development of greenhouse gas emissions are mentioned as important areas, along with market and judicial regulation to enforce environmental protection. It also mentions that the U.S. government expects to invest about two trillion dollars in environmental energy over 
four years, allowing innovative environmental technologies to revitalize the manufacturing industry.

The aggressive set of environmental policies adopted by Biden has significant political, military, diplomatic, and economic strategic considerations. The two major parties in the United States, Democrats, and Republicans lack political consensus on environmental policy. From a historical tradition, both at the level of global environmental governance and the level of domestic environmental governance, the democrats are more supportive of an aggressive environmental policy, while Republicans prefer conservative management and disapprove of too much government involvement in environmental matters. Thus, Biden campaigned on environmental promises, such as making the U.S. 100 percent clean energy and reaching net-zero carbon emissions by 2050. In addition, public opinion is also an aspect to consider. Over the past years, the Trump administration has repeatedly emphasized "America First" and performed negatively in environmental diplomacy such as addressing climate change and biodiversity conservation cooperation, which has seriously undermined U.S. leadership in global environmental governance and hindered the process of global sustainable development and has been condemned by the international community. Biden believes that taking positive actions is more conducive to demonstrating U.S. leadership. He has therefore actively pursued environmental diplomacy, fully integrating climate change into foreign policy and national security strategies. The BBC's climate change correspondent Douglas Magrath also notes that a "return to Paris" would mean that the United States would no longer pursue an "America First" unilateralism.

There are different voices around the world regarding the vision and promises made by the Biden administration. While the UN welcomes this, it also hopes that the US can show its sincerity. UN SecretaryGeneral Antonio Guterres stressed that international action to reduce emissions still has a long way to go. As the climate crisis continues to worsen, time is running out to achieve 1.5 degrees Celsius of temperature control and build more climate-resilient societies. He said he expects the United States to take a leadership role in accelerating global efforts to achieve net-zero carbon emissions. At the same time, the Biden administration has expanded the scope for U.S. and China cooperation in the climate sector. At present, the new U.S. government's new energy policy has taken a clear turn, to build a $100 \%$ clean energy economy and systematically planning energy and climate issues internally, and returning to the Paris Agreement externally as an opportunity to return to global climate governance and take control of the international climate cooperation process. China has also set the goal of achieving "carbon neutrality" by 2060 . This shows that the two countries have common interests in climate issues. As the world's two largest carbon emitters, the U.S. and China's cooperation is important for achieving the UN Sustainable Development Goals. But for the EU, their feelings are very complicated at this time. After Trump announced his withdrawal from the Paris Agreement, the EU still actively stated its firm position and insisted on pushing the Paris Agreement forward under the impact of the US withdrawal. It can be found that the Trump administration's "de-climatization" policy has not shaken the EU's expectations and confidence in the "low-carbon transition", instead, the EU continues to strengthen its internal climate and energy actions in various areas. The EU has undertaken several international climate diplomacy initiatives. This is reflected in the use of the UN platform to strengthen the follow-up negotiations and implementation of the Paris Agreement, and the use of the Conference of the Parties (COP) to maintain diplomatic relations with several countries in the climate alliance. Now, after Biden decided to return to the Paris Agreement, the EU has shown some concern after welcoming and supporting it. This stems from two main reasons. On the one hand, it is because the EU does not want that the return of the US will use its strong position to weaken the EU's voice and leadership, which is also related to the environmental interventions that will be mentioned later; on the other hand, the EU believes that the return of the US will affect its development and position in the energy technology industry. The Biden administration is willing to invest more money in the development of green energy and technology industries than the EU, which will strengthen competition and conflict.

Nevertheless, this does not mean that the U.S. government has intervened and pressured other countries, especially developing countries, less in environmental matters. One can only say that Biden has transformed some of that intervention into humanitarian intervention. For example, in an interview with Biden, as he took office, U.S. national climate adviser Gila McCarthy and presidential climate envoy John Kerry said that the current planning made by China on environmental protection and climate policy is still not good enough and called for further strengthening of emission reduction targets. From this, we can see that the U.S. remains tough on the environment, except that Biden has adopted a different circumlocution than Trump's confrontational conflict. This is one of the more worrying points for the EU as mentioned earlier. The EU has been cooperating fully with China on environmental and climate improvements for some time after the US withdrew from the Paris agreement, and the EU has been in a leadership role, driving the process of various meetings and projects. But after the US returns, it will not be willing to let the EU continue to take the lead, but wants to be the leader itself, so the US will be more assertive.

Essentially, Trump and Biden have the same aim in their policies towards China. Though belongs to the democrats' party, Biden is not traditional liberalism but a 
mature realist. He continues Trump's "America first" policies and didn't call of the trade tariffs Trump put up towards China, and he also claims to bring the important supply chain back to the US, which is also similar to Trump. Some scholars in China even see Biden's foreign policy as "Trumpism without Trump". But as a mature politician, Biden didn't give up US alliances and seek for a collaboration way to restrict China. Different from Trump's isolation, Biden use the traditional ideological ways to increase the US's global influences. If Trump has pushed his alliances away and some of them even come closer to China, then Biden is trying hard to fix them. By forming the AUKUS Alliance with Australia and the United Kingdom, the US is gradually returning to the traditional ways, by seeking to form another group against China.

\section{THE HISTORY OF LEGITIMIZATION OF HUMANITARIAN INTERVENTION}

The developed countries and the developing countries are having serious controversies towards environmental protection nowadays. While the developed countries accuse the developing countries of not shouldering the responsibilities to protect the environment and call for international intervention, the developing countries also blame the developed countries for violating their state sovereignty. The reason for this continuous debate has its historical roots. The developed countries, mostly the Western countries, have two traditions that contribute to their intervention---the tradition of political morality and the tradition to govern the mandate areas. It is the history of political morality that gave them the responsibilities to help form a better world. The idea that a stable world order should be morally righteous goes back to ancient Athens political philosophy, from Aristotle and Plato, and developed by Immanuel Kant. The idea of communal awareness came from Aristotle's theory to meld morals and ethics with politics. In Aristotle's work, "the politics of Aristotle" and "The Nicomachean Ethics", he emphasized self-realization from a moral perspective, unlike Machiavelli's idea that politics shouldn't involve moral or ethics problems. Similarly, The Allegory of the Cave was put forward by Plato, used to emphasize the role of philosophers, which were to walk out first and enlighten the other people in the cave. The allegory gave liberals in the Western countries a sense of responsibility to influence the so-called "barbarian countries" with more modern and advanced ideas from the West. In the 19th century, it was the idea of liberty, human rights, and freedom, while nowadays it changes to environmental protection. The tradition from ancient Athens influence Immanuel Kant, raising the idea of perpetual peace.

The idea of moral righteousness contributed not only to the rise of "scientific racism" in the 19th century but also support the Western imperialism and mandate systems, providing a perfect reason to intervene in the undeveloped area, under the name of helping with the modernity process. Due to this traditional mindset, some scholars in the later years even saw imperialism as right and justice. For example, Alfred Zimmern compared the British Empire with ancient Athens, thinking that they both stood for an example of disinterested virtue-based freedom. Jan Smuts believed that the world should be led by a league of nations dominated by the British and the US. While he didn't believe the so-called "lower race" can govern themselves, he conceived an idea of segregation between races and strict hierarchy in society. Zimmern and Smuts justified the imperialism actions, and today's Western scholars use the same idea to justify intervention towards the developing countries for their environmental issues. The two traditions give the Western countries both reason and responsibility to help the world become better, and better adapted to the common beliefs they hold. To achieve this, they might intervene or force the people who refuse to acknowledge these virtues. This explains why the developed countries nowadays are urgently encouraging and sometimes forcing the developing countries to keep up with their pace in environmental protection so that they could build a world accordant to the moralities they raised.

However, for developing countries, traditions towards international relations are quite different. Due to their general histories of being colonized or mandated, they regard sovereignty as the most important issue in international society, rather than the common values of "good" or "kind". The idea of sovereignty, established in the Treaty of Westphalia, was strengthened in the decolonization process. Refused to endow states and national borders with moral significance, the developing countries, mostly the non-Western countries, challenged the hierarchical and exclusionary international order, trying to form a universal society of states that was characterized by legal and political pluralism and set strict limitations on the exercise of foreign interference. Adom Getachew has argued in his article, "The limits of sovereignty as responsibility", that "the responsibility to protect engenders forms of authority that diminish the normative significance of state sovereignty while empowering institutions such as the Security Council. These institutional transformations reinforce a hierarchical international order, which in turn creates the conditions for specific practices" [10]. The idea of environmental protection can be compared with the principle of ' $\mathrm{R} 2 \mathrm{P}$ ', but change from protecting the people to protecting the environment. The intervention, either out of humanitarian consideration or environmental consideration, transforms the significance and responsibility to govern from state sovereignty to certain international institutions. Over time it will not only damage the power of state sovereignty but also bring more burden to the international society because when states take the paternalism intervention for granted, they will no longer perform their duties domestically. 
As stated above, the different histories of developed and developing countries influence how they think and react nowadays, and it should be seen from a global perspective. The global orders are formed by the Western countries or the developed countries, and they have established a global hierarchy that is dominated by the West. According to Amitav Acharya, it is the so-called "American world order". Environmental protection, a field that seems to be far away from politics, is also part of the world order. The developed countries need the developing countries to obey the rules they established, but the developing countries are eager to challenge the rules, longing for a more equal order. With the rapid development of non-Western countries, the global hierarchy will certainly be changed, which will also change how people react towards environmental protection at the same time. However, just as Acharya writes in his book, "the end of the American World Order", future global orders are likely to maintain the one led by the US, because the non-Western countries still can't manage important international issues like climate change. The developing countries are facing severe challenges nowadays. On the one hand, they claim today's world order is some kind of hegemony, and refuse to follow the environmental protection tasks given to them. On the other hand, they cannot form a new world order and still fail to handle some most important problems internationally. In other words, they face the contradiction of economic growth and environmental protection, still working hard to seek a solution. After all, with more populations and more territories in the world, the developing countries also have their responsibilities in climate change, and sovereignty can't be used as an excuse to pass the buck. According to the 2009 SecretaryGeneral Report, the responsibility to protect is a friend of sovereignty, not an adversary. Similarly, the responsibility to protect the environment shall not be an adversary for sovereignty, but something that can reinforce states' power and their international right of speech.

The conflict revolves around one word, "rights". In the case of developed countries, they have the right, as citizens living on the planet, to help build and improve the environment in which they live. According to an EPI survey on environmental protection conducted by the World Economic Forum, developed countries, especially European countries, are the most active and contributing to environmental protection. This shows that their sense of public awareness and responsibility for the environment has led them to use intervention and forceful means to promote environmental improvement and development for centuries. However, in the case of developing countries, which are under a lot of pressure because of the assertive stance of the developed countries, the "rights" they are talking about are more about sovereignty. They have been suffering from war and poverty since hundreds of years ago, and sovereignty is a core cohesion for them, giving them a great sense of security and sanctity. For them, the intervention of developed countries is not only a conflict between countries but also a disturbance and provocation to their "sovereignty" borderline caused by the high jurisdictional rights of developed countries over the international community.

In addition, the need for economic development for people's livelihood and national strength is another reason. This means that developing countries are willing to sacrifice part of their environment to promote their economy, such as the tropical relocation agriculture in Brazil, where people cultivate food by breaking the land of the Amazon rainforest, which is undoubtedly great harm to the Amazon rainforest and has caused many fires over the years, but the government is not able to take coercive measures to solve them. Because the people need to survive, a ban would only make their trust in the government fade away.

Since the fall of the Berlin Wall, and along with it the demise of communism and the ceasing of bipolar dominance of the world stage, international intervention has, for much of the time, been an issue that has dominated discourse in international law. Today's international intervention is more complicated that is intertwined with international law and the conflict of values. Since international intervention of all kinds has all faced numerous disputations in the field of international law, not to mention the huge discrepancy in values that different countries possess, the topic of intervention between developed and developing countries will remain to be essential in the future international world. The developed countries attempt to intervene, to be precise, is in defiance of the international law, because it is stated in The United Nations General Assembly's 1970 Declaration on Principles of International Law Concerning Friendly Relations, that "no state or group of states has the right to intervene, directly or indirectly, in the internal or external affairs of any other state. Consequently, armed intervention and all forms of interference or attempted threats against the personality of the state or its political, economic and cultural elements, violate international law." This is known as the principle of non-intervention and still seems to be well established in contemporary international law. Despite the regulations written, many humanitarian crises challenge people's psychological enduring capacity, which left a space for paternalistic intervention. It is not only about universal value virus sovereignty, but also a conflict between international law and the cardinal virtue we, as human beings, possess. In this way, developing countries like China turned a new way of coping with the intervention. Unlike the traditional way of simply refuting and denying, it began to construct a new system of value on its own. In 2012, president Xi of China first put forward the concept of "a community of shared future for mankind", implying that 
every country shared a common future in the earth and that all should work hard to preserve it. It is by the universal value raised by the West, but with a new form of expression. Although with similar meaning, it is very useful because it is a movement to try to form a new system of value, further form a new world order. The concept of human rights, environmental protection is widely used by the West, and countries like China do not have the right of speech previously, and it is hard for them to gain the right of speech based on the Western world order nowadays. China has already started to seek a new solution, to bypass the concept originated from the West and try to construct a new concept that can be used by themselves. Since international law is already set and unlikely to have a drastic change, future competition on the international right of speech would be unprecedentedly intense, mainly concentrating on the topic of values.

\section{CONCLUSION}

The fundamental fault of intervention, however wellintentioned, a fact that might lead to its failure, is that it is an ideal, a utopian idea that believes in the selfsacrifice of sovereign states when in reality intervention takes place for reasons of self-interest and power maximization, just as it did for the imperial powers. legal loopholes still exist, as does the lack of a legitimate or powerful authority being able to punish such states, which gives the more powerful states the ability to justify themselves intervening in weaker states, whether on grounds of humanitarianism or not. Humanitarian justifications should therefore govern our thinking about international intervention, whether military, economic or political, less than prima facie grounds of alleviating human rights violations and suffering might have us think.

\section{REFERENCES}

[1] Stowell, Ellery C. "Humanitarian Intervention." The American Journal of International Law 33, no. 4 (1939): 733-36. https://doi.org/10.2307/2192886.

[2] Heraclides, Alexis, and Ada Dialla. "Humanitarian Intervention Today." In Humanitarian Intervention in the Long Nineteenth Century: Setting the Precedent, 1-8. Manchester University Press, 2015. https://doi.org/10.2307/j.ctt1mf71b8.4.

[3] Fixdal, Mona, and Dan Smith. "Humanitarian Intervention and Just War." Mershon International Studies Review 42, no. 2 (1998): 283-312. https://doi.org/10.2307/254418.

[4] Bellamy, Alex J. "The Responsibility to Protect and the Problem of Military Intervention." International Affairs (Royal Institute of International Affairs 1944-) 84, no. 4 (2008): 615-39. http://www.jstor.org/stable/25144868.
[5] Paterson, Thomas G. "United States Intervention in Cuba, 1898: Interpretations of the SpanishAmerican-Cuban-Filipino War." The History Teacher 29, no. 3 (1996): 341-61. https://doi.org/10.2307/494551

[6] Sobel, Richard. "Trends: United States Intervention in Bosnia." The Public Opinion Quarterly 62, no. 2 (1998):

250-78. http://www.jstor.org/stable/2749625.

[7] FIOTT, DANIEL, Riccardo Alcaro, Niclas Poitiers, Jana Puglierin, Pauline Weil, and Guntram Wolff. "CONCLUSION: STRATEGIC SOVEREIGNTY AND INTERDEPENDENCE." Edited by Daniel Fiott. EUROPEAN SOVEREIGNTY: Strategy and Interdependence. European Union Institute for Security Studies (EUISS), 2021. http://www.jstor.org/stable/resrep34007.9.

[8] Friedberg, Aaron L. "The Future of U.S.-China Relations: Is Conflict Inevitable?" International Security 30, no. 2 (2005): 7-45. http://www.jstor.org/stable/4137594.

[9] Acharya, Amitav. "Human Security: East versus West." International Journal 56, no. 3 (2001): 442 60. https://doi.org/10.2307/40203577.

[10] Getachew, Adom. "Universalism After the PostColonial Turn: Interpreting the Haitian Revolution." Political Theory 44, no. 6 (2016): 821-45. https://www.jstor.org/stable/26419440. 